\title{
26 Research Square \\ Use of Site-Specific Data for Modeling Selenium Bioaccumulation by Terrestrial Animals
}

\author{
Gary Santolo ( $\nabla$ gsantolo@ch2m.com ) \\ CH2M HILL \\ Julie Yamamoto \\ University of California Davis \\ Harry Ohlendorf \\ Jacobs Engineering Group Inc Englewood
}

\section{Research Article}

Keywords: agricultural drainwater, bioaccumulation, food-chain model, Trophic Transfer Factor, Kesterson Reservoir, selenium, ecotoxicology.

Posted Date: April 30th, 2021

DOI: https://doi.org/10.21203/rs.3.rs-469153/v1

License: @ (i) This work is licensed under a Creative Commons Attribution 4.0 International License.

Read Full License

Version of Record: A version of this preprint was published at Archives of Environmental Contamination and Toxicology on March 14th, 2022. See the published version at https://doi.org/10.1007/s00244-02200917-8. 


\section{Abstract}

We developed a bioaccumulation model from an extensive set of monitoring data to predict selenium (Se) concentrations in biota within a terrestrial system (Kesterson Reservoir, CA). The model uses waterextractable Se concentrations in soil to estimate the expected range of mean Se concentrations in biota at Kesterson for future scenarios. Biological monitoring data collected at Kesterson Reservoir from 1988 to 1994 were used to parameterize the initial model. The model was tested and updated with additional sample results from 1995 through 2001 biological monitoring and validated and calibrated using Se concentrations from sampling conducted in 2004 and 2006. Minor adjustments were made to the model based on each additional year's results and the model was used in 2014 to assess whether there were continuing threats to wildlife at Kesterson. The model predicts Se concentrations in small mammals, bird blood, and bird eggs in common species found at Kesterson. This model was used for the final assessment of Kesterson in 2014 and performed well, but there was variability in results due to differences in individual diets and feeding ranges of animals. In the comparisons of 2014 predicted to measured Se, only whole-body mice, deer mice (Peromyscus maniculatus), and kestrel blood were significantly different. The trophic transfer factors and regression equations should be applicable to other Se-contaminated sites; adjusting weighting factors based on diet and range allows the model to be adapted and used at other sites.

\section{Introduction}

Kesterson Reservoir (hereafter, "Kesterson”) received subsurface agricultural drainwater contaminated with selenium (Se) in the late 1970s and early 1980s (Ohlendorf and Santolo 1994). Kesterson is in western Merced County, California, within the San Joaquin Valley $\left(37^{\circ} 15^{\prime} \mathrm{N}, 120^{\circ} 53^{\prime} \mathrm{W}\right)$. Severe adverse effects in aquatic birds led to remediation efforts by the U.S. Bureau of Reclamation in 1988 (Ohlendorf 2011; Ohlendorf et al. 2020). Kesterson, formerly a reservoir composed of 12 adjoining shallow ponds intended primarily for storage and evaporation of the drainwater, was dewatered and low-lying areas were filled with clean soil. Post-filling, Kesterson is a mosaic of filled areas, areas of preexisting grassland, and dewatered former cattail (Typha sp.) areas. Plant species at Kesterson are predominantly non-native annual forbs and grasses. Those species occur most abundantly in the more disturbed filled areas. In contrast, the less disturbed areas support dominant native plant species such as saltgrass (Distichlis spicata), which continues to dominate many of the grassland areas. Most of the former cattaildominated wetlands that were drained had a thick thatch layer that persisted over many years due to the lack of moisture for decomposition, partly because of the drought conditions through 1993. Those areas showed the greatest habitat change as the cattail thatch decomposed.

The filling transformed Kesterson into grassland and alkali scrub habitat used by terrestrial birds and other upland wildlife species (Ohlendorf and Santolo 1994). Risk assessments were conducted for Kesterson (CH2M HILL and Lawrence Berkeley National Laboratory 2000; Ohlendorf and Santolo 1994; Santolo 1994) using a bioaccumulation model developed on the basis of Kesterson sampling results in 1988 through 1994 (Santolo 1994). The model was tested and updated with additional sample results 
from 1995 through 2001 biological monitoring (Santolo unpublished data). Measured Se concentrations from sampling conducted in 2004 and 2006 were used to validate and calibrate the terrestrial Se bioaccumulation model. The model was used in 2014 to assess whether there were continuing threats to wildlife at Kesterson; the conclusion was that no further management actions were needed to mitigate or control exposures, and recommended that no further scheduled monitoring should occur (USBR 2015).

The original model was used to predict dietary Se concentrations for species such as red-tailed hawks (Buteo jamaicensis) and northern harriers (Circus cyaneus) 10 years into the future under varying assumptions of Se bioavailability (Ohlendorf and Santolo 1994) and was modified to assess the risk to waterbirds using ephemeral pools at Kesterson (Byron et al. 2003). Although field-sampling data indicated that model-predicted values were conservative, we concluded that long-term monitoring and management planning for Kesterson (Ohlendorf et al. 2020), and other sites with elevated Se, would benefit from an improved bioaccumulation model that uses the large database of site-specific and experimental information now available. Furthermore, the original model predicted dietary concentrations for receptors of interest, but a more refined model would provide estimates of accumulation in receptor tissues, particularly bird eggs, so that potential effects could be more directly and accurately evaluated.

In a wide variety of species, if one expresses Se concentrations in both the diet and eggs on a dry-weight basis, concentrations in bird eggs range from roughly equal to about three or four times those in the diet of the female at the time of egg-laying (Ohlendorf 2003). However, Se transfer from diet to eggs varies by species and likely by the chemical form, toxicokinetics, and metabolic pathways of the different Se forms in the diet (see: Davis et al. 2013; Davis et al. 2017; Heinz and Hoffman 1996; Tiwary et al. 2006). For example, when mallards (Anas platyrhynchos) were fed a diet containing $10 \mu \mathrm{g} \mathrm{Se} / \mathrm{g}$ as selenomethionine (SeMet), eggs from the treated birds contained a mean of about $15 \mu \mathrm{g} \mathrm{Se} / \mathrm{g}$ dry weight (dw) $(4.6 \mu \mathrm{g} \mathrm{Se} / \mathrm{g}$ wet weight [ww]), whereas eggs from those fed a diet containing $10 \mu \mathrm{g} \mathrm{Se} / \mathrm{g}$ as sodium selenite had only about $1.7 \mu \mathrm{g} \mathrm{Se} / \mathrm{g} \mathrm{dw}(0.53 \mu \mathrm{g} \mathrm{Se} / \mathrm{g} w w$; Heinz et al. 1987). In a study where quail were dosed with selenate $\left(\mathrm{SeO}^{4}\right)$ and the $\mathrm{L} / \mathrm{DL}$ isomeric mixture of SeMet (Santolo and Yamamoto, unpublished data), Se concentrations in the SeMet groups were higher in the protein fraction of the blood than the non-protein fraction (Se-L-Met, $\mathrm{F}_{1,40}=43.1, P<0.001$; Se-DL-Met, $\mathrm{F}_{1,40}=10.4, P=0.003$ ). However, there was no difference in Se concentration between protein and non-protein fractions of blood in the $\mathrm{SeO}^{4}$ group.

Trophic transfer factors (TTFs) from diet to bird eggs in laboratory studies tend to be higher than expected based on field data. In the laboratory studies, birds usually are exposed to a constant concentration and a single form of Se in their diets, whereas free-living animals are exposed to varied concentrations and different dietary forms of Se.

Few comprehensive studies of the effects of excessive Se on free-living terrestrial wildlife have been conducted (see Albers et al. 2000; Eisler 2000; Ohlendorf and Santolo 1994). Monitoring of terrestrial wildlife species (for example, CH2M HILL 1999), and studies of Se effects on free-living wildlife such as frogs and snakes (Ohlendorf et al. 1988), predatory birds (Santolo and Yamamoto 1999; Santolo and 
Yamamoto 2009), nesting songbirds (Santolo 2007), and small mammals (Clark Jr. 1987; Clark Jr. et al. 1989; Santolo 2009) have been conducted at Kesterson. There also have been very few laboratory studies investigating the effects of excessive Se on terrestrial avian predators (Santolo et al. 1999; eastern screech-owls [Otus asio]; Wiemeyer and Hoffman. 1996; Yamamoto and Santolo 2000; and American kestrels; Yamamoto et al. 1998). A TTF of about 0.8 was identified in reptiles (Sceloporus occidentalis) fed Se enriched ( $15 \mu \mathrm{g} / \mathrm{g}$ ) crickets (Acheta domesticus) by Hopkins et al, (2005) and no deleterious effects were observed. Those studies provide most of the available information on effects of Se to terrestrial wildlife species, and no guidelines have been established specifically for evaluating Se effects in terrestrial wildlife. Because of the limited data on effects of excess Se in free-living terrestrial animals, evaluation of effects in terrestrial systems is primarily extrapolated from effects on aquatic and semiaquatic species (birds) or domestic animals (poultry and mammals).

Bioaccumulation models have been extensively developed for Se in aquatic systems (e.g., Chapman et al. 2010; Presser and Luoma 2010; USEPA 2016), but comparable models have not been well developed for terrestrial systems. Here we describe a model developed from site-specific data for prediction of dietary Se exposure and consequent accumulation in terrestrial animals (i.e., invertebrates, herptiles, birds, and mammals) at Kesterson. For this model, empirical data are used to estimate uptake of Se from soils and co-located plants to diet to animals. Verification studies to assess the model's performance are also described. American kestrels, barn owls (Tyto alba), and loggerhead shrikes (Lanius ludovicianus) are predatory birds occurring year-round at Kesterson, and California voles (Microtus californicus), deer mice (Peromyscus maniculatus), and common small mammals as a group (i.e., deer mice, western harvest mice [Reithrodontomys megalotis], and house mice [Mus musculus] combined) at the site were selected as model species for this effort.

\section{Methods}

\section{Selenium Monitoring of Soil and Biota}

Soil, plant, and invertebrate samples were collected from 54 permanent sampling sites and bird, bird egg, and small mammal samples were collected from throughout Kesterson for Se analysis in $1989-2006$, and 2013/14 (USBR 2015). Se concentrations were determined for soil, above-ground plant parts, invertebrates, reptile livers and carcasses, bird livers, entire contents of bird eggs, and small mammal whole carcasses or livers. For mouse Se, three species were combined and a regression equation based on 1989 - 1998 liver:carcass Se concentrations in deer mice, western harvest mice, and house mice was developed to estimate whole-body Se concentrations when only livers were analyzed (Santolo 2009). Passerine Se concentrations were based on liver Se concentrations of 22 western meadowlarks (Sturnella neglecta) and two sparrows (Zonotrichia leucophrys gambelii) collected during 1989 and 1990. After 1994, additional Se determinations were conducted for bird blood samples collected at Kesterson.

Most samples were stored frozen until they were shipped to a commercial laboratory (Environmental Trace Substances Research Center, Columbia, Missouri from 1989 to 1991 or Laboratory and 
Environmental Testing, Columbia, Missouri after 1991) on dry ice for total Se analysis. Some bird blood samples were frozen, and then analyzed by California Animal Health and Food Safety (formerly California Veterinary Diagnostic Laboratory Service; University of California, Davis). Sample preparation consisted of lyophilization, followed by homogenization and sequential acid digestions (nitric acid followed by hydrochloric acid). Total Se concentrations were determined using hydride generation atomic absorption spectrometry. Blood was analyzed by hydride vapor generation inductively coupled argon plasma spectrometry (Tracy and Möller 1990). Lyophilization data were used to calculate percent moisture in all samples. All Se concentrations are expressed as $\mu \mathrm{g} / \mathrm{g}$ on a dry-weight (dw) basis.

\section{Model Development}

This terrestrial bioaccumulation model was based on an earlier model developed by Santolo (1994) and Ohlendorf and Santolo (1994) using data collected from 1988 -1994 for predicting Se concentrations in bird and mammal food chain items using measured water-extractable soil Se (WxSe) and enhanced by incorporation of subsequently collected data through 2001. The model was adjusted as new information became available from continued monitoring at Kesterson, supporting laboratory studies, and relevant literature.

About $93 \%$ of the Se inventory at Kesterson is immobile but slowly oxidizing into bioavailable forms (Wahl et al. 1994). Thus, the primary driving parameter for Se in the food chain is Se concentrations in soil water. This terrestrial bioaccumulation model uses measured WxSe concentrations in all years when samples were collected (not measured in 2014) to predict Se concentrations in food-chain items. Soil samples in 2014 were analyzed for total Se; WxSe was estimated using a regression equation based on 619 paired soil total Se and WxSe samples analyzed from 1989 to $2001\left(r^{2}=0.65 ; P<0.001\right)$. Se uptake by plants was then modeled using a regression equation based on paired soil and plant samples collected during biological monitoring at Kesterson. Although there is a general increase in plant Se with increasing WxSe, the relation between these two matrices is highly variable (Ohlendorf and Santolo 1994). Similarly, data from monitoring of plants, invertebrates, and vertebrates at Kesterson were used to develop Se trophic transfer factors (TTFs) through the food chain. We assumed that offsite diet item Se concentration was $1.9 \mu \mathrm{g} / \mathrm{g}$ based on small mammal offsite Se concentrations ( $2.0 \mu \mathrm{g} / \mathrm{g}$; Santolo 2009) and background concentrations reported by NIWQP $(<2.0 \mu \mathrm{g} / \mathrm{g}$ in mammals and $<1.5 \mu \mathrm{g} / \mathrm{g}$ in invertebrates; 1998), and similar to the mean Se concentration of $1.7 \mu \mathrm{g} / \mathrm{g}$ found in invertebrates collected from a nearby uncontaminated site, Volta Wildlife Area, near Kesterson (Hothem and Ohlendorf 1989). For insects and other consumers, a fractional weighting factor $(\leq 1)$ was assigned to each compartment of their diet and a TTF (concentration in the consumer divided by concentration in the food item) was determined. Weighting factors (WFs) were based on food habit and home range studies conducted at Kesterson whenever possible (e.g., Santolo unpublished data, Santolo 2007; Santolo and Yamamoto 2009). When site-specific data did not exist for Kesterson, data from other published sources were used (e.g., Marti et al. 2020; Vickerman and Trumble 2003; Yosef 1996). 
Regression analysis was used to develop TTFs, based on available measured Se concentrations from Kesterson biological monitoring, to simulate Se accumulation through the food-chain (e.g., from plant to herbivorous invertebrate or plant to herbivorous mammal). Detailed dietary, home range (Santolo and Yamamoto 2009), and experimental Se accumulation data for kestrels (Santolo et al. 1999; Yamamoto et al. 1998) were used to develop transfer and weighting factors for the Kesterson food-chain. Ohlendorf and Santolo (1994) previously described the equations used to develop these factors.

Se accumulation was weighted in two ways: (1) food habits were determined from direct studies at Kesterson (Santolo unpublished data, Santolo 2007; Santolo and Yamamoto 2009) or from the literature (e.g., Marti et al. 2020; Yosef and Lohrer 1995) to determine the proportion of the various dietary items in a species' diet; and (2) home ranges were determined from studies at Kesterson (Santolo unpublished data, Santolo and Yamamoto 2009) or from the literature (e.g., Marti et al. 2020; Yosef and Lohrer 1995)

and used to estimate the proportion of onsite foraging for various species. In addition, more recent results were used to adjust equations.

These regression models and weighting factors, along with species-specific diet data, were used to model Se accumulation in other species (such as barn owl and killdeer [Charadrius vociferus]). The percent of onsite foraging by other species was estimated using published foraging ranges and site-specific information such as where on Kesterson they tended to nest (Santolo unpublished data, Santolo 2007; Santolo and Yamamoto 2009).

\section{Model Testing, Verification, and Calibration}

Kesterson Se monitoring data collected from 1995 to 2001 (sampling methodology was similar from year-to-year, although not all sample types were collected in each year) were used to test and update the model. Results from sampling conducted in 2004 and 2006 were used to validate model assumptions and to calibrate the model. For each year, WxSe data were used as model input, and model predictions of Se concentrations in food-web species were compared to Se concentrations measured in biota for that year. These comparisons of modeled and measured Se concentrations provided a basis for evaluating the model's predictive value and improving the model's predictions. The final calibrated model was used to assess risk at Kesterson under conditions found in 2014 (USBR 2015).

Statistics

We used simple and second-order polynomial regression analysis to develop equations based on measured parameters for predicting Se concentrations (GraphPad Software 2020) and analysis of variance (ANOVA) to measure the quality of the models (SAS ${ }^{\circledR}$ Institute 1996; Zar 1974) or nonparametric Mann-Whitney tests (GraphPad Software 2020) to compare between values such as measured and predicted Se results.

\section{Results}


W $\times$ Se in soils was estimated from the regression equation described in Figure 1 (-0.747 * "log T-Se" -1.1733 ) for paired soil total Se and $W \times$ Se. Estimated $W \times$ Se for 54 soil samples in 2014 (when $W \times S e$ was not measured) was from 0.014 to $0.64 \mu \mathrm{g} / \mathrm{g}$ (geometric mean [GM] $=0.077 \mu \mathrm{g} / \mathrm{g}$ ), with $\mathrm{W} \times \mathrm{Se}$ about $6.8 \%$ of total Se.

Paired samples were also used to describe the relation between detritus and $\mathrm{W} \times \mathrm{Se}$ concentrations $\left(r^{2}=\right.$ $0.51, n=103, P<0.001)$. Detritus Se concentrations were estimated using the following regression equation:

Detritus $[\mathrm{Se}]=\left(10^{(1.773+0.29102 \times(\log \mathrm{W} \times \mathrm{Se})}\right)$

The log-log relation between paired plant and WxSe $\left(r^{2}=0.398, n=90, P<0.001\right.$; Figure 2A) or total soil Se (Figure 2B) concentrations $\left(r^{2}=0.399, n=90, P<0.001\right)$ were examined and there was no difference between the two calculations $(P=0.528)$. The following models describe WxSe and total soil Se to plant Se:

Plant $[\mathrm{Se}]=\left(10^{(0.335 \times \log \mathrm{W} \times \mathrm{Se}+0.808}\right)$

Plant $[\mathrm{Se}]=\left(10^{(0.280 \times \log \mathrm{TSe}+0.405)}\right.$

We used the geometric means of Se by trisection (Ohlendorf and Santolo 1994) for samples from 1988 to 2006 to relate total soil Se, WxSe, and plant Se to Se in herbivorous invertebrates. The plant to herbivorous invertebrate regression $\left(r^{2}=0.335, n=84, P<0.001\right)$ was not as strong as (i.e., more variable than) the relation between total soil Se $\left(r^{2}=0.397, n=81, P<0.001\right)$ or WxSe and herbivorous invertebrate $\operatorname{Se}\left(r^{2}=0.492, n=81, P<0.001\right)$ :

Herbivorous Invertebrate $[\mathrm{Se}]=\left(10^{(0.227 \times \text { Log TsoilSe }+0.780}\right)$

Herbivorous Invertebrate $[\mathrm{Se}]=\left(10^{(0.288 \times \log \mathrm{W} \times \mathrm{Se}+1.12)}\right.$

Carnivorous invertebrate Se then was related to herbivorous invertebrate $\operatorname{Se}\left(r^{2}=0.335, n=80, P<0.001\right)$ by the regression equation:

Carnivorous Invertebrate $[\mathrm{Se}]=\left(10^{(0.549 \times \text { Log HerbInv }+0.610}\right)$

Previous studies using kestrels fed seleno-L-methionine mixed into a commercial meat-based diet (Yamamoto et al. 1998) described the relation between diet and blood Se $\left(r^{2}=0.91, n=157, P<0.001\right)$. However, because birds at Kesterson (and presumably other contaminated sites) feed on diet items with a range of Se concentrations, a correction factor was used for calculating blood and egg Se from the assumed diet. In the study by Yamamoto et al. (1998), one group of American kestrels were fed a prepared diet (i.e., $9 \mu \mathrm{g} / \mathrm{g}$ as SeMet) and another group were fed animals collected at Kesterson with a 
similar mean concentration ( $8 \mu \mathrm{g} \mathrm{Se} / \mathrm{g})$, and blood samples were taken during the time they were being fed these diets on Days 14, 35 and 56; the difference in blood Se ranged from 45 to 88 percent. The average difference of 0.76 was used as the initial correction factor for diet to blood Se:

Kestrel blood $[\mathrm{Se}]=\left(10^{((0.345+0.552 \times(\text { Log kestrel diet }[\mathrm{Se}]) \times 0.76)}\right)$

We used the kestrel blood Se equation for estimating barn owl blood Se but adjusted the correction factor to $50 \%$ based on measured barn owl blood Se from previous years:

Barn owl blood $\left[\right.$ Se] $=\left(10^{((0.345 \times(\text { Log barn owl diet }[\text { Se] }+0.552) \times 0.50)}\right)$

Paired samples of Se in starling (Sturnus vulgaris) diet and their blood Se (Santolo 2007) were used to describe the relation between passerine diet and blood Se concentrations $\left(r^{2}=0.47, n=9, P=0.042\right)$. In addition, we assumed that Se uptake from plant and invertebrate diets was less than complete and used an initial correction factor of 0.70 . Passerine blood Se concentrations were estimated using the following regression equation:

Passerine blood $[\mathrm{Se}]=\left(\left(10^{((0.524 \times(\log \operatorname{Diet}[\mathrm{Se}]+0.447)) \times 0.70)}\right)\right.$

The passerine blood Se equation was used to calculate shrike blood Se but because their dietary items include vertebrates, we used the maximum correction factor from the kestrel study of $88 \%$ as the initial assumption, so shrike blood Se was estimated using the following regression equation:

Shrike blood $\left[\right.$ Se] $=\left(\left(10^{((0.524+0.447 \times(\text { Log Diet }[\text { Se }])) \times 0.88)}\right)\right.$

We did not have paired diet:blood samples for killdeer so we used the kestrel blood Se equation for killdeer blood and assumed that, because they are invertivores, the correction factor would be similar to kestrels and shrikes and used 0.85 as the initial correction factor:

Killdeer blood $[\mathrm{Se}]=\left(10^{((0.345+0.59 \times(\text { Log killdeer diet }[\mathrm{Se}]) \times 0.85)}\right)$

Santolo and Yamamoto (1999) estimated concentrations of egg Se for free-living birds using a blood-toegg Se concentration relation established in captive American kestrel studies (Santolo et al. 1999) and assumed the relation to be similar for other predatory birds. However, the relation was developed from birds fed a constant elevated concentration of SeMet in their diet, which over-estimated egg Se in wild birds because free-living birds would be exposed to various concentrations and forms of Se in their diets. For example, at Kesterson invertebrate Se ranged from 0.6 to $48 \mu \mathrm{g} \mathrm{Se} / \mathrm{g}$ in 1994 and 1995 (Santolo and Yamamoto 1999), and small mammal Se concentrations ranged from 2.4 to $37 \mu \mathrm{g} \mathrm{Se} / \mathrm{g}$ in 1999 (Santolo 2009); we used the antilog of parent blood Se and $76 \%$ as the initial correction factor:

Egg Se $=10^{\wedge}(\log$ parent blood Se $\left.) \times 0.76\right)$ 
Paired samples of Se in starling blood and egg Se (Santolo 2007) were used to describe the relation between passerine blood and egg Se concentrations $\left(r^{2}=0.74, n=5, P=0.002\right)$. Passerine egg Se concentrations were estimated using the following regression equation:

Passerine Egg $[\mathrm{Se}]=\left(10^{((0.42+0.28 \times(\log B \text { Blood }[\mathrm{Se}]))}\right)$

We used the passerine egg equation for loggerhead shrike eggs and, because of the exclusive animal diet of this species, we assumed greater Se uptake from the diet and applied a correction factor of 0.90 and used the following equation:

Loggerhead Shrike Egg $[\mathrm{Se}]=\left(\left(10^{((0.42+0.28 \times(\log \text { Blood }[\text { Se }]))}\right) \times 0.9\right)$

Blood samples of female adult California gulls (Larus californicus) and eggs $\left(r^{2}=0.45, n=12, P=0.012\right.$ ) from the Great Salt Lake, Utah (Conover and Vest 2009) were used to describe the relation between killdeer egg and blood Se concentrations. Killdeer egg Se concentrations were estimated using the following regression equation:

Killdeer Egg $\left[\right.$ Se] $=\left(10^{(1.72+2.32 \times(\text { Log Killdeer Blood }[\text { Se] }]) \times 0.001}\right)$

\section{Trophic Transfer Factors}

TTFs were used when there were not individually paired samples of consumers and their diet or no strong relationship was found. For some, a TTF was used in the initial model, but as more samples were collected, it became clear that there was a significant relation and a regression equation was developed and added to the model.

Because Se concentrations in carnivorous invertebrates were significantly higher than concentrations in herbivorous invertebrates (non-carnivores; $P<0.001$ ), terrestrial invertebrates were separated into categories of herbivorous insects ( 1,046 samples; $39 \%$ were herbivorous beetles [Coleoptera], $12 \%$ were crickets, and $48 \%$ were grasshoppers [Orthoptera]) and carnivorous invertebrates (435 samples of which $6 \%$ were mantids [Orthoptera], $10 \%$ were scarab beetles [Scarabaeidae], and $84 \%$ were spiders [Arachnida]). We assumed that terrestrial non-carnivorous insects were eating only plants. The TTF was based on 667 spatially and temporally paired plant and insect samples collected from 1989 to 1994, as follows:

Herbivorous insect $[\mathrm{Se}]=($ Plant $[\mathrm{Se}]) \times 2.8$

We assumed that carnivorous invertebrates were eating only insects. The TTF was based on 218 spatially and temporally paired spider and insect samples collected from 1989 to 1994, described as follows:

Carnivorous invertebrate $[\mathrm{Se}]=($ Herbivorous insect $[\mathrm{Se}]) \times 1.5$ 
We assumed that small reptiles (lizards and small snakes [i.e., $\leq 15 \mathrm{~cm}$ ) that are eaten by American kestrels and loggerhead shrikes because of their small size would likely be eating only arthropods and that there is a higher abundance of herbivorous insects than carnivorous invertebrates in most years. We chose dietary WFs to be 70\% herbivorous insects and 30\% carnivorous invertebrates. Few lizards had been observed at Kesterson since the 1990s and they were not caught in pitfall traps or found in kestrel pellets during sampling at Kesterson. Common kingsnakes (Lampropeltis getulus), common garter snakes (Thamnophis sirtalis), and gopher snakes (Pituophis catenifer catenifer) had been observed during monitoring at Kesterson, and six gopher snakes were captured and analyzed for whole body Se concentrations in 1989 and three in 1990 (Santolo, unpublished data). Thus, a TTF was calculated based on these spatially and temporally paired gopher snake and insect samples:

Small reptile $[\mathrm{Se}]=($ Herbivorous insect $[\mathrm{Se}] \times 0.7+$ Carnivorous invertebrate $[\mathrm{Se}] \times 0.3) \times 1.43$

Diets and WFs for voles were determined from stomach content analysis of 55 California voles captured at Kesterson (Santolo, unpublished data). Only trace amounts of invertebrates were observed in diets and they were likely consumed incidentally during feeding. The TTF was based on spatially and temporally paired plant, invertebrate, and vole samples collected from 1989 to 1994, as follows.

California vole $($ whole-body $)[$ Se] $=($ Plant $[$ Se] $\times 0.991+$ Herbivorous insect $[$ Se $] \times 0.009) \times 2.009$

We assumed that predatory birds at Kesterson did not discriminate between deer mice, western harvest mice, and house mice and fed on them based on availability. Therefore, we combined these species (mice) for predator diets. Deer mice were also modeled separately. Diets and WFs for mice were determined from stomach content analysis of 158 deer mice, 47 western harvest mice, and 84 house mice captured at Kesterson (Santolo, unpublished data). The TTF was based on 390 spatially and temporally paired plant, invertebrate, and mouse samples collected from 1989 to 1994, as follows.

Mice $($ whole-body $)[\mathrm{Se}]=($ Plant $[\mathrm{Se}] \times 0.794+$ Mushroom $[\mathrm{Se}] \times 0.004+$ Herbivorous insect $[$ Se $] \times 0.101+$ Carnivorous invertebrate $[\mathrm{Se}] \times 0.101) \times 1.485$

Diets and WFs for American kestrels at Kesterson were determined from examination of 31 pellets collected from kestrel nest boxes at Kesterson (Santolo and Yamamoto 2009). The fraction of onsite and offsite foraging is the estimated area and time that is spent foraging on Kesterson and offsite food items and is expressed as a percent in the model.

American kestrel diet [Se] $=(($ Herbivorous insect $[\mathrm{Se}] \times 0.45+$ Carnivorous invertebrate $[\mathrm{Se}] \times 0.30+$ Reptile $[\mathrm{Se}] \times 0.01+$ Passerine $[\mathrm{Se}] \times 0.09+$ Mice $[\mathrm{Se}] \times 0.16) / 5) \times(\%$ onsite foraging $)+(\%$ offsite foraging $\times 1.9)$ )

Diets and WFs for shrikes were determined from the literature (Yosef and Lohrer 1995) and site observations. Because most shrike blood was collected during the fall and winter, the diet was adjusted to be dominated by vertebrate species that would be available as prey during that time: 
Loggerhead shrike diet $[\mathrm{Se}]=(($ Herbivorous insect $[\mathrm{Se}] \times 0.10+$ Carnivorous invertebrate $[\mathrm{Se}] \times 0.14+$ Reptile $[\mathrm{Se}] \times 0.10+$ Passerine $[\mathrm{Se}] \times 0.11+$ Mice $[\mathrm{Se}] \times 0.55) / 5) \times(\%$ onsite foraging $)+(\%$ offsite foraging $\times 1.9)$ )

Diets and WFs for barn owls were determined from the literature (Marti et al. 2020) and site observations. Because most barn owl blood was collected during the fall and winter, the diet was adjusted to be dominated by vertebrate species that would be available as prey during that time:

Barn owl diet $[\mathrm{Se}]=(($ Passerine $[\mathrm{Se}] \times 0.018+$ Mice $[\mathrm{Se}] \times 0.032+$ Vole $[\mathrm{Se}] \times 0.95) / 3) \times(\%$ onsite foraging $)+(\%$ offsite foraging $\times 1.9))$

Diets and WFs for passerines were determined from stomach content analysis of nine western meadowlarks collected at Kesterson. Passerines were assumed to forage only within Kesterson. The TTF was based on 22 spatially and temporally paired plant and invertebrate samples collected from 1989 to 1994:

Passerine diet $[\mathrm{Se}]=($ Soil $[\mathrm{Se}] \times 0.03+$ Plant $[\mathrm{Se}] \times 0.12+$ Herbivorous insect $[\mathrm{Se}] \times 0.58+$ Carnivorous invertebrate $[\mathrm{Se}] \times 0.33) \times 1.024$

Diets and WFs for killdeer were determined from the literature (Jackson and Jackson 2000) and site observations. Except for 1990, aquatic invertebrates were not collected from Kesterson during sampling after 1988 when aquatic habitats were removed for mitigation (Ohlendorf and Santolo 1994; Ohlendorf et al. 2020). Carnivorous invertebrates were assumed to have similar concentrations of Se and were used in diet calculations for killdeer. Also, because killdeer were found almost exclusively using the perimeter of Kesterson (mostly along the drainage canal on the east side), we assumed that their diet included offsite invertebrates as well:

Killdeer diet $[$ Se] $=(($ Carnivorous invertebrate $[$ Se $]) \times(60 \%$ onsite foraging $))+(40 \%$ offsite foraging $\times 1.9))$

\section{Model Testing, Verification, and Calibration}

For the model testing and verification, we used the measured W×Se for 1995, 1996, 1998, and 2001, which included a range of dry to wet years. The model was run, and means were compared to measured results for the year, so the model was tested and updated with additional sample results each year through 2001 biological monitoring. The results from sampling conducted in 2004 and 2006 were used to validate and further calibrate the terrestrial Se bioaccumulation model. The results for each of the years are based on the model calibrated using the previous year's results.

The model performed well when compared to the results for 1995; Se concentrations modeled in the various plants and animals ranged from $99 \%$ to $160 \%$ of the measured sample results. Measured and predicted results were significantly different only for voles and kestrel blood. The model predicted Se concentrations that were significantly higher than those measured for voles $(P=0.002)$ and kestrel blood Se $(P=0.025)$. 
Plants and invertebrates were not sampled in 1996 but WxSe was measured and used in the model. Before running the model with the 1996 WxSe results we made a minor change based on the 1995 results by reducing the percentage of onsite feeding of kestrels from $58 \%$ to $50 \%$ and increasing the correction factor from 0.76 to 0.88 . The 1996 predictions ranged from $60 \%$ to $135 \%$ of measured sample results. Three predicted results were significantly different from measured results. Se in whole-body deer mice $(P$ $=0.027)$ and blood Se in passerines $(P=0.006)$ were significantly higher than measured concentrations and predicted shrike blood Se was significantly lower $(P<0.001)$ than measured in 1996.

Using adjustments made from 1996 sampling for 1998 comparisons, the model predictions ranged from $65 \%$ to $120 \%$ of measured Se for plants and animals. The predicted Se concentrations were significantly lower than measured Se for carnivorous invertebrates $(P<0.001)$ and killdeer eggs $(P=0.002)$. The model reasonably predicted concentrations in all other media and similarly predicted concentrations in eggs of kestrels, barn owls, shrikes, and killdeer.

For 2001 comparisons, Se concentrations predicted for mice $(P<0.001)$, deer mice $(P=0.013)$, shrike blood $(P=0.008)$, and killdeer eggs $(P=0.016)$ were all significantly higher than measured concentrations, and passerine and barn owl blood predicted Se concentrations were significantly lower than the measured Se concentrations.

Results from limited monitoring conducted in 2004 and 2006 were added to the model to be used for comparison to the 2014 monitoring results (Table 1). For 2014, WxSe was not analyzed and no invertebrate samples were collected for analysis. The adjusted model predictions ranged from $62 \%$ to $206 \%$ of 2014 measured Se for various media. Kestrel blood samples were all from birds using nest boxes on Kesterson, so the predicted onsite foraging was increased from $50 \%$ to $75 \%$. Also, based on the results from 2001, the killdeer correction factor was changed from 0.85 to 0.75 prior to running the model. Mouse and deer mouse predicted Se concentrations were significantly higher than measured Se $(P<$ 0.001 for both). Only kestrel blood Se prediction was significantly lower than measured Se. The model reasonably predicted concentrations in all other media and similarly predicted concentrations in eggs of kestrels, barn owls, and shrikes.

\section{Discussion}

Se concentrations at Kesterson are highly variable both temporally and spatially (Clark Jr. 1987; Hothem and Ohlendorf 1989; Ohlendorf and Santolo 1994; Saiki and Lowe 1987; Schuler et al. 1990; Wahl et al. 1994). However, long-term terrestrial monitoring data provided relatively accurate model predictions for birds (the ecological receptors of primary concern at the site), based on verification and calibration exercises carried out with data for various biological media in several post-remediation years $(1995,1996$, $1998,2001,2004,2006$, and 2014). The analytical techniques used in the terrestrial habitat models are based on a series of linear and log-linear relations and TTFs among environmental variables. In each case, assumptions are made about the underlying distribution of the data and the appropriateness of the relation in explaining covariance of the variables. As is to be expected from environmental monitoring 
data, there remains unexplained variation in the predictions, even in cases of statistically significant relations. However, the basic assumption of the models is that the predictive relations are all descriptive of underlying causal relations.

Unlike aquatic models for fish in enclosed water bodies, terrestrial species can be in or out of the contaminated area, and therefore exposed to a greater range of Se concentrations. The model shows that predicting Se concentrations in species with greater foraging ranges, and therefore a greater range of dietary Se concentrations, becomes less accurate, as would be expected. However, the model produces a range of concentrations that represent the range of potential tissue concentrations. Familiarity with the species being evaluated and how the species use the site and the habitat on the site are important for making professional judgments on such things as species diet and percent of foraging onsite and offsite help to reduce variability in the model. The model's predicted results do not encompass the entire range of Se concentrations observed in measured samples but instead, the predicted results have less variability and cluster around the mean (Figure 3 ).

This Se food chain model allows for adjustments to individual species based on dietary items, which can change by season or habitat, and by estimated onsite and offsite foraging. This allows the model to be adjusted for different seasons and for different size sites where a species foraging range may be all or just part of the contaminated area.

Comparison of model outputs to monitoring data produced several significant discrepancies. In 1998, unusual Se dynamics in the food chain probably occurred because of a higher-than-normal rainfall (El Niño storm events) that year and also likely affected species foraging ranges and availability of dietary items. For example, in 1998, Se concentrations were higher in terrestrial invertebrates than during most other years (CH2M HILL 1999). In addition, terrestrial birds, such as loggerhead shrikes and kestrels, were observed foraging offsite to a greater degree during the breeding season, while aquatic-associated species, such as killdeer, may have had the opportunity to forage onsite more because much of Kesterson was flooded.

This model assumes that animals use all the habitats at Kesterson and may not predict Se concentrations accurately in animals that use any single habitat type exclusively or in those that forage primarily offsite, which has been shown to mitigate Se in such birds (Santolo 2007). Also, this model is based on Kesterson-specific data but Se uptake from the diet would likely be similar at other sites. Although the regression models and TTFs are likely not site-specific, adaptation by incorporation of sitespecific data for other sites would improve the predictions at those sites. Nevertheless, our model shows the possibility of modeling for terrestrial environments at a level comparable to the much greater effort that has focused on the aquatic environment (e.g., Chapman et al. 2010; Presser and Luoma 2010; USEPA 2016).

Predicted Se concentrations provided a realistic range of Se in biota based on water-extractable soil Se concentrations and, in many cases, total soil Se. Therefore, this model can be used, with limited sampling for verification, to reduce the monitoring effort and cost at Kesterson and potentially at other high-Se 
sites. However, if water-extractable or soil Se concentrations are unavailable, the model can provide predictions using data from any starting point within the food-chain (e.g., plant or invertebrate Se concentrations).

\section{Declarations}

Funding Funding for this research was provided by the U.S. Bureau of Reclamation under contract number 9-CS-20S00440 for the Kesterson Reservoir biological monitoring program.

Conflicts of interest/Competing interests The authors have no conflicts of interest to declare that are relevant to the content of this article.

Availability of data and material The datasets generated during and/or analyzed during the current study are available from the corresponding author on reasonable request.

Code availability Not applicable.

Acknowledgments -The authors are grateful to M. Delamore for his support, M. Eisert, C. Green, and C. Johnson for their contributions to this monitoring program and N. Williams (deceased) for valuable comments on an earlier version of this model.

\section{SUPPLEMENTAL DATA}

The measured Se concentrations in soil and measured and predicted Se concentrations in various biological media, the percent difference between measured and predicted Se as a percent of measured Se, and the significance ( $P$-value) of predicted versus measured comparisons for 1995, 1996, 1998, and 2001 are provided online as a Supplemental Data file to support the information summarized in this paper.

\section{References}

1. Albers PH, Heinz GH, Ohlendorf HM (2000) Environmental contaminants and terrestrial vertebrates : effects on populations, communities, and ecosystems. Society of Environmental Toxicology and Chemistry, Pensacola, FL

2. Byron ER, Ohlendorf HM, Santolo GM, et al. (2003) Ecological risk assessment example: Water and shorebirds feeding in ephemeral pools at Kesterson Reservoir, California. In: Hoffman DJ, Rattner BA, Burton Jr GA, Cairns Jr J (eds) Handbook of Ecotoxicology. 2nd edn. Lewis Publishers, New York, p 985-1014

3. CH2M HILL (1999) Kesterson Reservoir 1998 Biological Monitoring. Prepared for U.S. Bureau of Reclamation, Mid-Pacific Region by CH2M HILL, Sacramento, CA

4. CH2M HILL and Lawrence Berkeley National Laboratory (2000) Ecological Risk Assessment for Kesterson Reservoir. Prepared for the U.S. Bureau of Reclamation, Sacramento, CA 
5. Chapman PM, Adams WJ, Brooks ML, et al. (2010) Ecological assessment of selenium in the aquatic environment: Summary of a SETAC Pellston Workshop. CRC Press, Boca Raton, FL

6. Clark Jr. DR (1987) Selenium accumulation in mammals exposed to contaminated California irrigation drainwater. Science of the Total Environment 66:147-168

7. Clark Jr. DR, Ogasawara PA, Smith GJ, Ohlendorf HM (1989) Selenium accumulation by raccoons exposed to irrigation drainwater at Kesterson National Wildlife Refuge, California, 1986. Archives of Environmental Contamination and Toxicology 18:787-794

8. Conover MR, Vest JL (2009) Concentrations of selenium and mercury in eared grebes (Podiceps nigricollis) from Utah's Great Salt Lake, USA. Environ Toxicol Chem 28(2):324-329 doi:10.1897/08214.1

9. Davis TZ, Stegelmeier BL, Welch KD, Pfister JA, Panter KE, Hall JO (2013) Comparative oral dose toxicokinetics of selenium compounds commonly found in selenium accumulator plants. J Anim Sci 91(9):4501-9 doi:10.2527/jas.2012-6101

10. Davis TZ, Tiwary AK, Stegelmeier BL, Pfister JA, Panter KE, Hall JO (2017) Comparative oral dose toxicokinetics of sodium selenite and selenomethionine. J Appl Toxicol 37(2):231-238 doi:10.1002/jat.3350

11. Eisler R (2000) Selenium Handbook of Chemical Risk Assessment: Health Hazards to Humans, Plants, and Animals. Volume 3: Metalloids, Radiation, Cumulative Index to Chemicals and Species. vol 3. Lewis Publishers, Boca Raton, FL., p 1649-1,705

12. GraphPad Software (2020) GraphPad Prism 8 Version 9.0.0 for Windows. San Diego, CA

13. Heinz GH, Hoffman DJ (1996) Comparison of the effects of seleno-L-methionine, seleno-DLmethionine, and selenized yeast on reproduction of mallards. Environ Pollut 91(2):169-175

14. Heinz GH, Hoffman DJ, Krynitsky AJ, Weller. DMG (1987) Reproduction in mallards fed selenium. Environ Toxicol Chem 6:423-433

15. Hopkins WA, Staub BP, Baionno JA, Jackson BP, Talent LG (2005) Transfer of selenium from prey to predators in a simulated terrestrial food chain. Environ Pollut 134(3):447-456

16. Hothem RL, Ohlendorf HM (1989) Contaminants in foods of aquatic birds at Kesterson Reservoir, California, 1985. Arch Environ Contam Toxicol 18(6):773-786 doi:10.1007/bf01160291

17. Jackson BJ, Jackson JA (2000) Killdeer (Charadrius vociferus). In: Poole AF, Gill FB (eds) The Birds of North America Online. Cornell Lab of Ornithology, Ithaca, NY

18. Marti CD, Poole AF, Bevier LR, et al. (2020) Barn Owl (Tyto alba). In: Billerman SM (ed) The Birds of the World Online. vol 1. Cornell Lab of Ornithology, Ithaca, NY

19. National Irrigation Water Quality Program (NIWQP) (1998) Guidelines for the Interpretation of Biological Effects of Selected Constituents in Biota, Water, and Sediment Information Report No. 3. National Irrigation Water Quality Program, Department of the Interior. Denver, CO, Washington, D.C.

20. Ohlendorf HM (2003) Ecotoxicology of selenium. In: Hoffman DJ, Rattner BA, Burton Jr GA, Cairns Jr $\mathrm{J}$ (eds) Handbook of Ecotoxicology, Second Edition. CRC Press, Boca Raton, FL, p 465-500 
21. Ohlendorf HM (2011) Selenium, salty water, and deformed birds. In: Elliott JE, Bishop CA, Morrissey CA (eds) Wildlife Ecotoxicology. Emerging Topics in Ecotoxicology, vol 3. Springer, New York, NY, p 325-357

22. Ohlendorf HM, Hothem RL, Aldrich. TW (1988) Bioaccumulation of selenium by snakes and frogs in the San Joaquin Valley, California. Copeia 3:704-710

23. Ohlendorf HM, Santolo GM (1994) Kesterson Reservoir-past, present, and future: An ecological risk assessment. In: W.T. Frankenberger Jr., Benson S (eds) Selenium in the Environment. Marcel Dekker, Inc., New York, NY, p 69-117

24. Ohlendorf HM, Santolo GM, Byron ER, Eisert MA (2020) Kesterson Reservoir: 30 years of selenium risk assessment and management. Integr Environ Assess Manag 16(2):257-268 doi:10.1002/ieam.4222

25. Presser TS, Luoma SN (2010) A methodology for ecosystem-scale modeling of selenium. Integr Environ Assess Manag 6(4):685-710 doi:10.1002/ieam.101

26. Saiki MK, Lowe TP (1987) Selenium in aquatic organisms from subsurface agricultural drainage water, San Joaquin Valley, California. Arch Environ Contam Toxicol 16:657-670

27. Santolo GM (1994) Ecological risk assessment for Kesterson Reservoir, Merced County, California. M. S. Thesis. University of California Davis, University of California, Davis

28. Santolo GM (2007) Selenium accumulation in European starlings nesting in a seleniumcontaminated environment. Condor 109:863-870

29. Santolo GM (2009) Small mammals collected from a site with elevated selenium concentrations and three reference sites. Arch Environ Contam Toxicol 57:741-754

30. Santolo GM, Yamamoto JT (1999) Selenium in blood of predatory birds from Kesterson Reservoir and other areas of California. J Wildl Manage 63(4):1273-1281

31. Santolo GM, Yamamoto JT (2009) Nest box and site use by, and selenium concentrations in, American kestrels at Kesterson Reservoir, central California. J Raptor Res 43:315-324

32. Santolo GM, Yamamoto JT, Pisenti JM, Wilson BW (1999) Selenium accumulation and effects on reproduction in captive American kestrels fed selenomethionine. J Wildl Manage 63(2):502-511

33. SAS® Institute (1996) Statview computer statistical package version 4.57, Cary, NC

34. Schuler CA, Anthony RG, Ohlendorf HM (1990) Selenium in wetlands and waterfowl foods at Kesterson Reservoir, California, 1984. Arch Environ Contam Toxicol 19(6):845-853 doi:10.1007/bf01055049

35. Tiwary AK, Stegelmeier BL, Panter KE, James LF, Hall JO (2006) Comparative toxicosis of sodium selenite and selenomethionine in lambs. J Vet Diagn Investig 18(1):61-70 doi:10.1177/104063870601800108

36. Tracy ML, Möller G (1990) Continuous flow vapor generation for inductively coupled argon plasma spectrometric analysis. Part 1: selenium. J Assoc Off Anal Chem 73:404-410 
37. U.S. Bureau of Reclamation (USBR) (2015) Kesterson Reservoir 2013/2014 Biological Monitoring Report. In: [USBR] US Bureau of Reclamation (ed). Prepared by CH2M HILL, Mid-Pacific Region: Sacramento (CA)

38. U.S. Environmental Protection Agency (USEPA) (2016) Aquatic Life Ambient Water Quality Criterion for Selenium - Freshwater 2016. EPA 822-R-16-006. Office of Water, Office of Science and Technology., U.S. Environmental Protection Agency, Washington, D.C.

39. Vickerman DB, Trumble JT (2003) Biotransfer of selenium: Effects on an insect predator, Podisus maculiventris. Ecotoxicology 12(6):497-504

40. Wahl C, Benson S, Santolo G (1994) Temporal and spatial monitoring of soil selenium at Kesterson Reservoir, California. Water, Air and Soil Pollution 74:345-361

41. Wiemeyer SN, Hoffman. DJ (1996) Reproduction in eastern screech-owls fed selenium. J Wildl Manage 60(2):332-341

42. Yamamoto JT, Santolo GM (2000) Body condition effects in American kestrels fed selenomethionine. J Wildl Dis 36:646-652

43. Yamamoto JT, Santolo GM, Wilson BW (1998) American kestrels (Falco sparverius) fed selenomethionine and naturally incorporated selenium. Environ Toxicol Chem 17:2494-2497

44. Yosef R (1996) Loggerhead Shrike (Lanius Iudovicianus). In: Poole A, Gill FB (eds) The Birds of North America. vol 231. Cornell Lab of Ornithology, Ithaca, NY

45. Yosef R, Lohrer FE (1995) Shrikes (Lanidae) of the world: biology and conservation. Proc West Found Vertebr Zool 6(1):343 pp.

46. Zar JH (1974) Biostatistical analysis. Prentice-Hall, Englewood Cliffs, New Jersey, USA

\section{Tables}

Table 1. Selenium concentrations in soil and measured and predicted selenium concentrations ${ }^{\mathrm{a}}$ in various biological media, 2014. 


\begin{tabular}{|c|c|c|c|c|c|}
\hline & \multicolumn{3}{|c|}{ Measured } & \multicolumn{2}{|l|}{ Predicted } \\
\hline Media & $n$ & Range & GM & Model GM (Range) & $\%$ of Measured $(P)$ \\
\hline \multicolumn{4}{|l|}{ Soil (WxSe) } & \multicolumn{2}{|l|}{$0.073(0.007-0.56)$} \\
\hline Soil & 52 & $0.11-19$ & 1.1 & & \\
\hline Plants & 136 & $0.54-22$ & 3.2 & $2.7(1.2-5.3)$ & $84(0.236)$ \\
\hline \multicolumn{4}{|l|}{ Insects } & \multicolumn{2}{|l|}{$6.2(3.1-11)$} \\
\hline \multicolumn{4}{|l|}{ Carnivorous Invertebrates } & \multicolumn{2}{|l|}{$11(7.6-15)$} \\
\hline Mice $^{\mathrm{c}}$ & 69 & $0.8-23$ & 4.5 & $5.5(3.0-9.3)$ & $122(<0.001)$ \\
\hline Deer mice & 33 & $0.5-8.3$ & 2.8 & $5.8(3.2-9.8)$ & $206(<0.001)$ \\
\hline Passerines $^{d}$ & 15 & $4.0-34$ & 9.8 & $8.2(6.9-9.3)$ & $83(0.051)$ \\
\hline Kestrel blood ${ }^{\mathrm{e}}$ & 5 & $5.7-11$ & 7.6 & $4.7(4.0-5.5)$ & $62(<0.001)$ \\
\hline Kestrel egg ${ }^{\mathrm{e}}$ & 3 & $3.2-5.9$ & 4.4 & $3.6(3.0-4.2)$ & $82(0.303)$ \\
\hline Barn owl blood ${ }^{f}$ & 2 & $2.4-2.5$ & 2.5 & $2.4(2.2-2.9)$ & $97(0.554)$ \\
\hline Shrike bloodg & 14 & $2.0-15$ & 7.6 & $7.4(6.2-8.7)$ & $98(0.154)$ \\
\hline Shrike egg ${ }^{g}$ & 3 & $2.9-4.0$ & 3.5 & $3.9(3.6-4.2)$ & $111(0.144)$ \\
\hline Killdeer egg ${ }^{h}$ & 7 & $2.0-9.6$ & 3.8 & $4.0(3.2-4.9)$ & $106(0.591)$ \\
\hline \multicolumn{6}{|c|}{ a Based on 2001 measured water-extractable soil selenium } \\
\hline \multicolumn{6}{|c|}{ b Weighted by percent onsite and offsite foraging } \\
\hline \multicolumn{6}{|l|}{${ }^{\mathrm{C}}$ Whole-body Se } \\
\hline \multicolumn{6}{|l|}{${ }^{\mathrm{d}}$ Blood Se } \\
\hline \multicolumn{6}{|c|}{ e American kestrels were assumed to forage onsite $75 \%$ based on nest box use } \\
\hline \multicolumn{6}{|c|}{${ }^{f}$ Barn owls were assumed to forage onsite $55 \%$} \\
\hline \multicolumn{6}{|c|}{${ }^{g}$ Loggerhead shrikes were assumed to forage onsite $99 \%$} \\
\hline $\begin{array}{l}\mathrm{h} \text { Killdeer were assumed tc } \\
\text { reduced to } 0.75 \text {. }\end{array}$ & rage & site $60 \%$. & ed on & 2001 model results the & orrection factor was \\
\hline
\end{tabular}

\section{Figures}




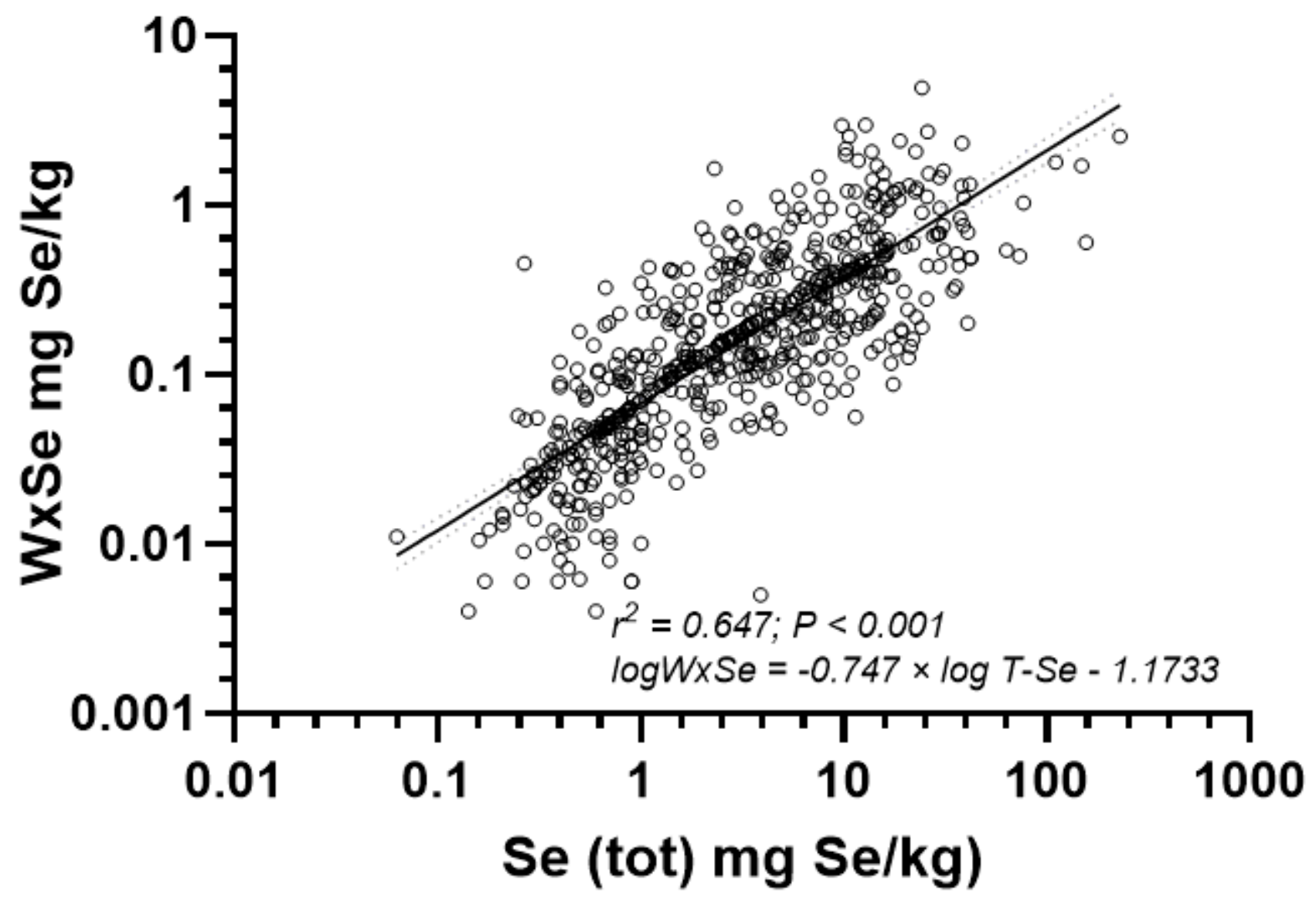

Figure 1

Relation between total soil (tot) and water-extractable $(\mathrm{W} \times \mathrm{Se})$ soil selenium in 621 paired samples collected from Kesterson, 1989 to 2006. 

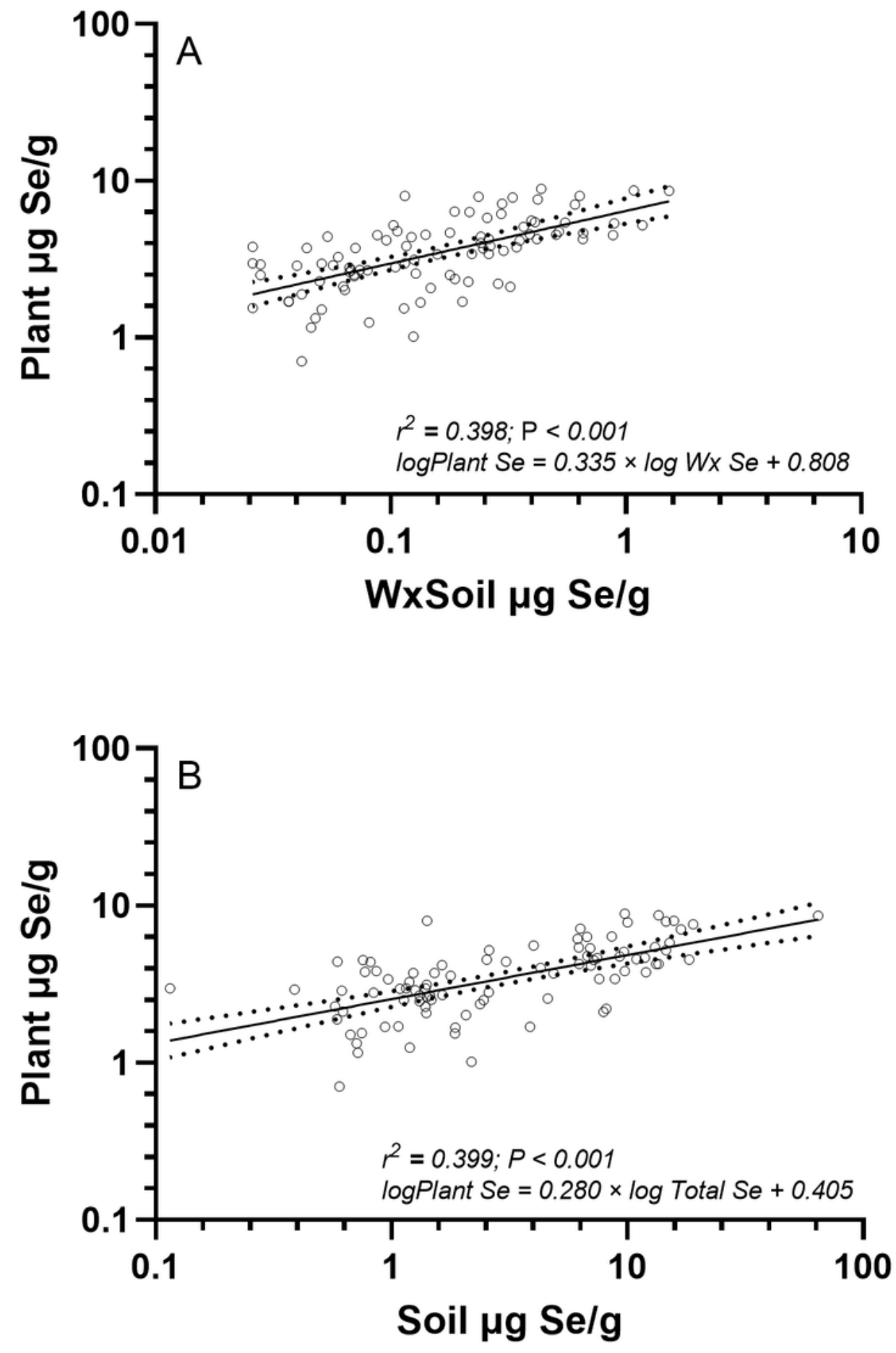

Figure 2

Relations between mean selenium concentrations $(\mu \mathrm{g} / \mathrm{g})$ in plants and total soil selenium $(A ; P<0.001)$ and water-extractable selenium in soil $(\mathrm{B} ; \mathrm{P}<0.001)$ at Kesterson, $1989-2006$. 


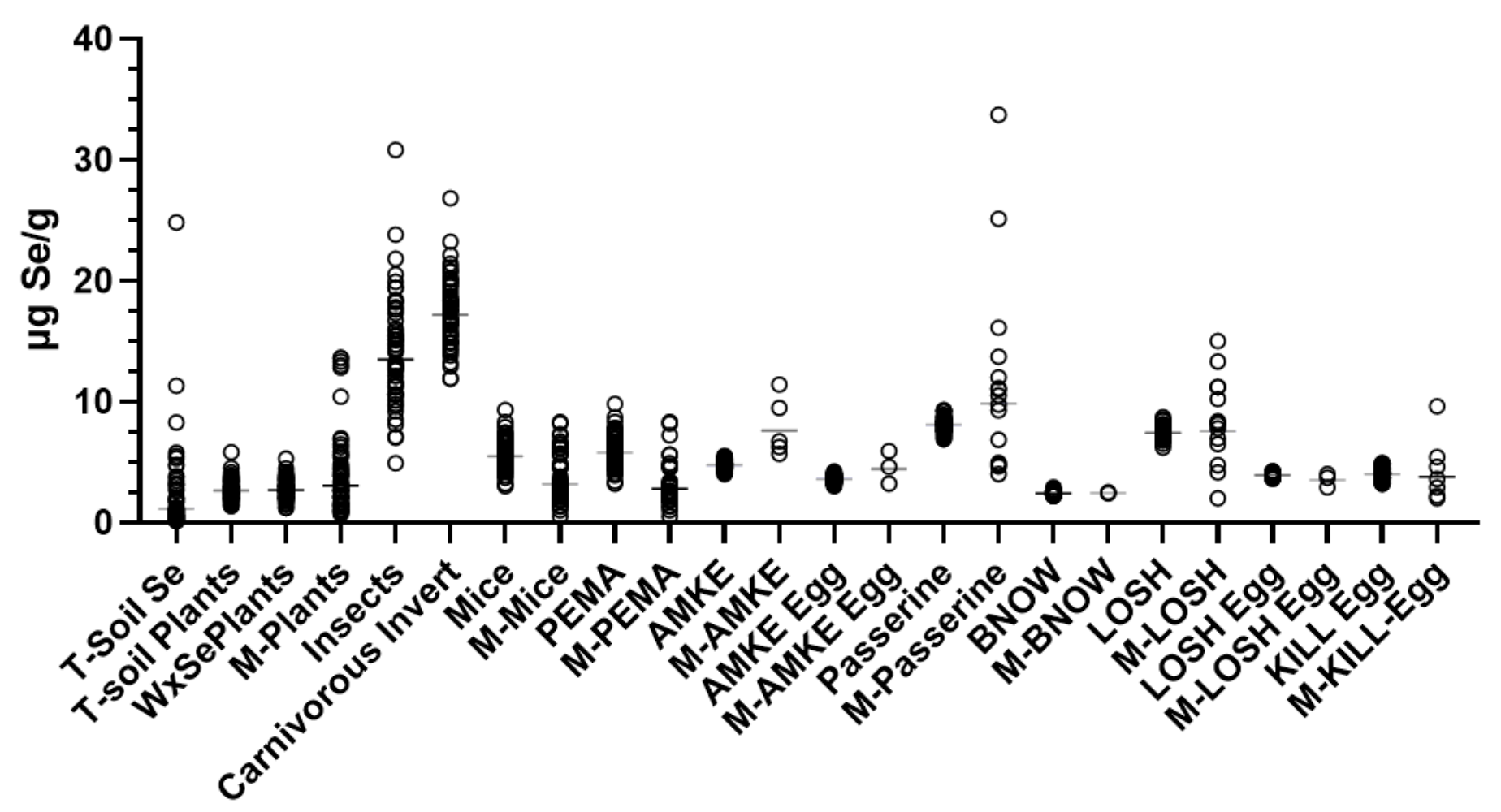

Figure 3

2014 Modeled and measured (M-) selenium (geometric means and individual samples) of total (T-) soil Se, plant Se predicted from total soil Se (T-soil plant), plant Se predicted from WxSe (WxSePlants), measured Se in plants (M-Plant), predicted Se in Herbivorous Insects, predicted Se in Carnivorous Invertebrates, predicted Se in whole-body Mice (deer mice, western harvest mice, and house mice), measured Se in whole-body mice (M-Mice), predicted Se in American kestrel blood (AMKE), measured Se in American kestrel blood (M-AMKE), ), predicted Se in American kestrel eggs (AMKE Egg), measured Se in American kestrel eggs (M-AMKE Egg), predicted Se in Passerine blood, measured Se in Passerine blood (M-Passerine), predicted Se in barn owl blood (BNOW), measured Se in barn owl blood (M-BNOW), ), predicted Se in loggerhead shrike blood (LOSH), measured Se in loggerhead shrike blood (M-LOSH), predicted Se in loggerhead shrike eggs (LOSH Egg), measured Se in loggerhead shrike eggs (M-LOSH Egg), predicted Se in killdeer eggs (KILL Egg), measured Se in killdeer (M-KILL Egg) from Kesterson Reservoir.

\section{Supplementary Files}

This is a list of supplementary files associated with this preprint. Click to download.

- SeModelMSSupplementalDataTables.docx 